\title{
Migrasi Orang Jawa di Kecamatan Lilirilau Kabupaten Soppeng (1998-2018)
}

\author{
Patahuddin, Bahri, Muh. Fadly \\ Program Studi Pendidikan Sejarah, Fakultas Ilmu Sosial Universitas \\ Negeri Makassar \\ Email: patahuddin@unm.ac.id,bahri@unm.ac.id,fadlyfathel@gmail.com
}

\begin{abstract}
This study aims to determine the migration life of Javanese people in Lilirilau Subdistrict, Soppeng Regency, by describing the background of their arrival, socio-economic life and the impact of their existence. This study uses historical research methods which include heuristics, namely the collection of data or sources, source criticism to assess and determine the original and false sources, interpretation or interpretation and historiographic stages or historical writing. The results showed that, the background of Javanese arrivals in Lilirilau District was influenced by economic factors because the opportunity to get better jobs in the destination area (Soppeng) was better than the area of origin (Java). The Javanese interaction with the people of Lilirilau is cultural interaction (language and other social activities) and economic interaction (buyers and sellers in markets and stalls and other economic activities). Javanese solidarity in Lilirilau sub-district is woven through the community that conducts social gathering and recitation activities. Javanese in Lilirilau Subdistrict work in the culinary field. The existence of the Javanese has an impact on the social, economic and cultural. Their presence received a good response by the local community, so that it did not cause social problems in the District of Lilirilau.
\end{abstract}

\section{Keywords: Migrasi, Javanese, Soppeng}

Abstrak: Penelitian ini bertujuan untuk mengetahui kehidupan migrasi orang Jawa di Kecamatan Lilirilau Kabupaten Soppeng, dengan menguraikan latar belakang kedatangan, kehidupan sosial-ekonomi dan dampak keberadaannya. Penelitian ini menggunakan metode penelitian sejarah yang meliputi heuristik yaitu pengumpulan data atau sumber, kritik sumber untuk menilai dan menentukan sumber asli dan palsu, interpretasi atau penafsiran dan tahap historiografi atau penulisan sejarah. Hasil penelitian menunjukkan bahwa, latar belakang kedatangan orang Jawa di Kecamatan Lilirilau dipengaruhi faktor ekonomi karena kesempatan untuk mendapatkan pekerjaan yang lebih baik di daerah tujuan (Soppeng) lebih baik dibandingkan dengan daerah asal (Jawa). Adapun Interaksi orang Jawa dengan masyarakat Lilirilau adalah interaksi budaya (bahasa dan kegiatan-kegiatan kemasyarakatan lainnya) dan interaksi ekonomi (penjual-pembeli di pasar dan warung serta kegiatan ekonomi lainnya). Solidaritas orang Jawa di Kecamatan Lilirilau dijalin melalui paguyuban yang melakukan kegiatan arisan dan pengajian. Orang Jawa di Kecamatan Lilirilau banyak berprofesi dibidang kuliner. Keberadaan orang Jawa memberikan dampak di bidang sosial,ekonomi dan budaya. Keberadaan mereka mendapat respon yang baik oleh masyarakat lokal, sehingga tidak menimbulkan masalah sosial di Kecamatan Lilirilau.

Kata Kunci: Migrasi, Orang Jawa, Soppeng 


\section{PENDAHULUAN}

Indonesia merupakan negara kepulauan terbesar di dunia, terdiri dari 13.667 pulau dengan keadaan geografis yang tidak sama. Hal ini menyebabkan penduduk disetiap pulau mengembangkan pola hidup yang berbeda-beda, tumbuh menjadi kesatuan suku bangsa yang hidup terisolasi dari suku bangsa lainnya. Setiap suku bangsa tersebut tumbuh menjadi kelompok masyarakat yang majemuk. Masyarakat majemuk adalah masyarakat yang terbagi-bagi kedalam subsistem yang kurang lebih berdiri sendiri-sendiri, yang setiap subsistemnya terikat dalam ikatan-ikatan yang bersifat primordial (Setiadi \& Kolip, 2013).

Ledakan kepadatan penduduk selalu menjadi isu yang dikaitkan dengan berbagai permasalahan yang ada pada suatu wilayah. Penduduk akan melakukan mobilitas setiap waktunya, mobilitas yang dimaksud adalah lebih ditekankan pada pergerakan dalam upaya peningkatan kesejahteraan hidup (Indira, Mulyadi, \& Nasrullah, 2019). Permasalahan dalam kepadatan penduduk adalah persebaran yang tidak merata (Christiani, Tedjo, \& Martono, 2014).

Dari data sensus penduduk tahun 2000, tingkat kepadatan penduduk rata-rata 109 jiwa per $\mathrm{km}^{2}$, sebenarnya Indonesia bukan merupakan negara yang berpenduduk terlalu padat. Masalah utama yang dihadapi dalam kaitannya dengan kepadatan penduduk tersebut adalah persebarannya yang tidak merata, sekitar 60\% dari jumlah penduduk Indonesia tinggal di Pulau Jawa yang luasnya hanya 6,7\% dari luas daratan Indonesia. Sementara Kalimantan sebagai pulau terluas di Indonesia yaitu 28,1\% dari luas daratan Indonesia, hanya dihuni oleh sekitar 5,1\% dari jumlah penduduk Indonesia. Papua yang luas 22\% dari 
luas daratan Indonesia, hanya dihuni oleh sekitar $1 \%$ dari jumlah penduduk Indonesia (Warsono, 2005).

Kepadatan penduduk di Pulau Jawa sebagai salah satu faktor pendorong bermigrasi ke daerah lain. Selain itu, rasa kurang puas dengan kehidupan sosial ekonomi di tempat asal serta ada yang bermigrasi atas kemauan sendiri yang didorong oleh faktor dari daerah asalnya dan faktor menarik tempat tujuan migrasi. Suatu fenomena yang telah menjadi gejala umum bahwa apabila suatu daerah yang mempunyai potensi untuk tumbuh dan berkembang utamanya dalam bidang ekonomi, maka daerah tersebut akan menjadi daya tarik bagi para migran untuk datang dan bertempat tinggal di daerah tersebut. Para migran itu biasannya datang secara spontanitas atau bujukan dari teman, tetangga, kerabat, yang telah berhasil di daerah perantauan tersebut (Rahmi, 2016).

Lee (1992) mengungkapkan bahwa faktor yang melatarbelakangi migrasi tenaga kerja ke daerah tujuan adalah faktor makro yang lebih dikenal dengan daya tarik (pull factor) di daerah tujuan dan daya dorong (push factor) dari daerah asal. Sampai saat ini, motif ekonomi dipandang sebagai faktor pendorong utama bagi seseorang untuk melakukan mobilitas (Alkhudri, Dharmawan, Kinseng, \& Tjondronegoro, 2018). Keberadaan orang Jawa sebagai pendatang, sehingga terjadi kontak sosial dengan suku Bugis yang merupakan penduduk asli wilayah Kabupaten Soppeng, khususnya di Kecamatan Lilirilau. Terjadinya kontak sosial antar kelompok masyarakat dengan latar belakang etnis yang berbeda, maka suku Jawa merupakan kelompok masyarakat pendatang harus beradaptasi terhadap lingkungan budaya suku Bugis. 
Proses adaptasi tersebut menuntut dua hal pokok, sebagai syarat bagi kelangsungan hidup dan kehidupan dari setiap kelompok masyarakat. Pertama, kemampuan bagi pelaku adaptasi untuk memahami dan mengetahui lingkungannya, dan yang kedua, adalah kemampuan bagi pelaku adaptasi untuk menyerap umpan balik secara baik dengan lingkungannya (Bachtiar , 2004). Orang Jawa memiliki keterampilan serta keuletan dan ketekunan dalam mengerjakan sesuatu. Orang Jawa yang bermigrasi di Kabupaten Soppeng umumnya bermata pencaharian pedagang kuliner.

Pasar tradisonal Cabbengge merupakan pusat perdagangan penting di Soppeng, karena lalu lintas hasil bumi dari Bone, Wajo, bahkan dari Toraja, berdatangan untuk melakukan transaksi jual beli (Hasanuddin \& Bernadetra, 2016). Hal ini yang menjadi alasan orang Jawa memilih lokasi untuk bermigrasi di Kecamatan Lilirilau yang beribukota di Cabbengge.

\section{METODE}

Metode penelitian yang digunakan dalam penelitian ini adalah metode penelitian deskriptif dengan pendekatan penelitian sejarah. Penelitian sejarah terdiri dari 4 langkah. 1) heuristik, mengumpulkan sumber sejarah yang memiliki keterkaitan dengan penelitian. 2) kritik, data yang didapatkan, dikritik untuk memperoleh fakta-fakta yang subjektif (Sejarah, 1975). 3) interpretasi, pemaknaan fakta sejarah. Faktafakta sejarah dapat diuraikan dan disatukan sehingga berkaitan dengan makna satu sama yang lainnya. 4) historiografi, menuangkan seluruh kemampuan, bukan saja keterampilan teknis penggunaan kutipan dan catatan-catatan, yang paling utama yakni penggunaan pikiran-pikiran 
kritis dan analisanya karena sejarawan pada akhirnya harus menghasilkan sintesis dari seluruh hasil penelitiannya atau penemuannya itu dalam suatu penulisan utuh (Sjamsuddin \& Nursam, 2007).

\section{HASIL DAN PEMBAHASAN}

\section{Gambaran Umum Lokasi Penelitian}

Kabupaten Soppeng merupakan salah satu kabupaten yang ada di Provinsi Sulawesi Selatan yang terletak di Selatan Kota Makassar, berjarak sekitar $\pm 174 \mathrm{~km}$ melalui Buludua, atau $\pm 235 \mathrm{~km}$ melalui Sidenreng Rappang. Berada diantara $4^{0} 06^{\prime}$ LS-4036' LS dan 119042'18'"-12006'13" BT (BPS, 2018). Kecamatan Lilirilau merupakan salah satu kecamatan diantara 8 kecamatan yang ada di Kabupaten Soppeng, dengan luas 187 $\mathrm{km}^{2}$. Berjarak $12 \mathrm{~km}$ dari Watansoppeng yang merupakan ibukota kabupaten. Kecamatan Lilirilau terdiri dari 8 desa dan 4 kelurahan diantaranya: Desa Paroto, Desa Palangiseng, Desa Tetewatu, Desa Abbanuange, Desa Parenring, Desa Masing, Desa Baringeng, Kelurahan Pajalesang, Kelurahan Cabenge, Kelurahan Macanre, Kelurahan Ujung. Secara astronomi Kecamatan Lilirilau berada pada $4^{\circ} 06^{\prime} 0^{\prime \prime}-44^{\underline{9}} 2^{\prime} 0^{\prime \prime}$ LS

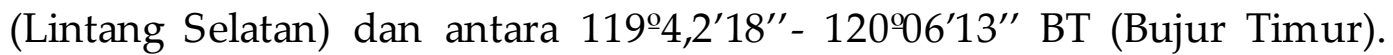
Adapun batas-batas wilayah Kecamatan Lilirilau antara lain: bagian Utara berbatasan Kabupaten Wajo, bagian Timur berbatasan Kabupaten Bone, bagian Selatan berbatasan Kecamatan Liliriaja, bagian Barat berbatasan Kecamatan Ganra.

Jumlah penduduk di Kecamatan Lilirilau sebanyak 38.733 jiwa dengan jumlah laki-laki sebanyak 18.140 jiwa dan perempuan sebanyak 20.593 jiwa, hal ini menunjukkan bahwa perbedaan jumlah laki-laki dan 
perempuan tidak jauh berbeda dengan selisih jumlah yang berjenis kelamin perempuan lebih banyak.

Penduduk di Kecamatan Lilirilau yang bekerja keras untuk memenuhi kebutuhannya dengan melakukan berbagai pekerjaan. Mata pencaharian penduduk suatu daerah atau suatu wilayah tertentu banyak dipengaruhi oleh kondisi lingkungan alam dan keterampilan yang dimiliki oleh masyarakatnya. Dengan keadaan alam Kecamatan Lilirilau yang berada pada ketinggian 10-190 meter dari permukaan air laut sangat memungkinkan penduduk Kecamatan Lilirilau bermata pencaharian pada bidang agraris (bertani dan berkebun). Berdasarkan data yang dihimpun dari Badan Pusat Statistik Kabupaten Soppeng produksi padi di Kecamatan Lilirilau pada tahun 2011, sebanyak 9.135 ton yang dihasilkan dari luas panen seluas 1.827 Ha. Hasil perkebunan rakyat yang utama adalah kakao, kelapa, jambu mete, dan tembakau.

\section{Kedatangan Orang Jawa di Lilrilau}

Pada tahun 1970-an jumlah orang Jawa yang bermigrasi di Kecamatan Liirilau masih sangat sedikit. Namun, seiring berjalannya waktu keberadaan orang Jawa di Kecamatan Lilirilau Kabupaten Soppeng sudah semakin bertambah. Pada tahun 1998 kedatangan orang Jawa di Kecamatan Lilirilau secara besar-besaran karena dipengaruhi oleh krisis ekonomi yang terjadi di Indonesia.

Pada dasarnya perpindahan suatu kelompok atau individu masyarakat tidak berjalan tanpa adanya faktor, baik itu faktor pendorong yang menjadi alasan untuk meninggalkan daerah asalnya, dan faktor penarik yang menjadi alasan pemilihan daerah tujuan. Kedua faktor ini sangat mempengaruhi dan saling berkaitan satu sama lain. Dalam 
keputusan bermigrasi selalu terkandung keinginan untuk memperbaiki salah satu aspek kehidupan, sehingga seseorang melakukan migrasi disebabkan oleh berbagai macam faktor, sama halnya dengan orang Jawa di Kecamatan Lilirilau yang melakukan migrasi yang disebabkan oleh dua faktor yaitu faktor pendorong dan faktor penarik tersebut. Faktor-faktor pendorong migrasi yaitu:

1. Makin berkurangnya sumber-sumber alam, menurunnya permintaan atas barang-barang tertentu yang bahan bakunya makin susah diperoleh seperti hasil tambang, kayu atau bahan dari pertanian

2. Menyempitnya lapangan pekerjaan ditempat asal (misalnya di pedesaan) akibat masuknya teknologi yang menggunakan mesinmesin (capital intensive).

3. Adanya tekanan-tekanan atau diskriminasi politik, agama, suku di daerah asal.

4. Tidak cocok lagi dengan adat/ budaya/ kepercayaan di tempat asal

5. Alasan pekerjaan atau perkawinan yang menyebabkan tidak bisa mengembangkan karir pribadi.

6. Bencana alam baik banjir, kebakaran, gempa bumi, musim kemarau panjang atau adanya wabah penyakit (Munir, 1981).

Salah satu faktor pendorong migran Jawa melakukan migrasi ke Kecamatan Lilirilau adalah faktor yang berasal dari daerah asal. Minimnya lapangan kerja, serta faktor sumber daya alam yang semakin berkurang mengakibatkan orang Jawa melakukan migrasi di Kecamatan Lilirilau. Hal tersebut sebagaimana yang dituturkan: "di Jawa hanya menjadi buruh pabrik dan tenaga yang dibutuhkan sangat sedikit. 
Sedangkan merantau bisa membuka usaha sendiri karena lapangan kerja masih tersedia" (Listianti, 2019). Akibat lapangan pekerjaan yang terbatas membuat mereka ingin merantau, jika tetap bertahan di Jawa apalagi tidak memiliki pendidikan yang tinggi dan keahlian, mereka akan kesulitan untuk mendapatkan pekerjaan dengan alasan sebagian besar lapangan pekerjaan yang ada di Jawa adalah pada sektor industri yang membutuhkan pendidikan dan keahlian pada bidang tersebut.

Keinginan untuk memenuhi kebutuhan ekonomi menjadi alasan migran Jawa melakukan migrasi dengan cita-cita mendapatkan kehidupan yang lebih layak di daerah rantau. Alasan merantau karena ingin memperbaiki ekonomi keluarga. Usaha mebel dan ukiran di Jawa sudah banyak, sementara di Soppeng, khususnya di Lilirilau sangat kurang" (Saifuddin, 2019). Faktor ekonomi menjadi salah satu pendorong untuk melakukan migrasi dengan alasan persaingan yang terjadi di Jawa, sehingga peluang untuk mendapatkan penghasilan semakin menurun. Selain faktor ekonomi, faktor lain yang menjadi pendorong migrasi yaitu alasan perkawinan. Migran Jawa yang bermigrasi di Kecamatan Lilirilau Kabupaten Soppeng, seperti yang dialami oleh Nengsih yang menikah dengan orang Soppeng ketika bekerja di Morowali Sulawesi Tengah, kemudian memilih hijrah ke Soppeng kampung halaman suaminya (Nengsih, 2019).

\section{Interaksi Migran Jawa dengan Penduduk Lokal}

Kehadiran migran dalam suatu komunitas akan memberi pengaruh terhadap kehidupan sosial masyarakat setempat. Kehadiran migran tersebut akan memberikan perubahan dari masyarakat homogen menjadi masyarakat yang heterogen (majemuk). Demikian halnya pada 
masyarakat di Kecamatan Lilirilau Kabupaten Soppeng, kehadiran para migran khususnya migran Jawa yang datang ke Kecamatan Lilirilau Kabupaten Soppeng akan menimbulkan terjadinya akulturasi di dalam masyarakat, dimana setiap etnik memiliki latar belakang budaya masingmasing. Konsekuensinya akan melahirkan norma atau aturan yang akan diterapkan bersama dalam berinteraksi satu sama lain terutama yang berbeda etnik. Masyarakat pendatang menyesuaikan diri (adaptasi) dengan norma atau aturan yang berlaku pada masyarakat setempat. Begitu pula dengan yang terjadi pada masyarakat Jawa di Kecamatan Lilirilau mampu beradaptasi dengan masyarakat Kecamatan Lilirilau yang bersuku Bugis.

Migran Jawa memiliki bahasa daerah Jawa dan masyarakat Kecamatan Lilirilau menggunakan bahasa Bugis sebagai bahasa seharihari. Sikap masyarakat lokal sebagai mayoritas untuk terjadinya interkasi dengan orang Jawa, menggunakan Bahasa Indonesia walaupun terkadang diselingi dengan bahasa Bugis. Seiring berjalannya waktu, orang Jawa mulai memahami Bahasa Bugis walaupun belum fasih dalam pengucapannya. Sebagian migran Jawa di Lilirilau pernah tinggal di Makassar dan daerah lainnya di Sulawesi Selatan sehingga sudah memahami bahasa Bugis, namun pengucapannya belum fasih (Riadi, 2019) (Saifuddin, 2019). Bahasa Indonesia sangat bermanfaat menyatukan suku yang multi etnis, termasuk suku Bugis dan Jawa di Lilirilau.

Hubungan harmonis Bugis-Jawa ditunjukkan, ketika orang Bugis memiliki hajatan, mengundang orang Jawa menghadirinya. Hal ini disampaikan Anita Sari bahwa "Soppeng sudah menjadi kampung saya karena bersuamikan penduduk asli, sehingga setiap hajatan yang 
dilakukan oleh tetangga dihadirinya (Sari, 2019), sedangkan Listianti menghadiri hajatan karena alasan memiliki hubugan yang baik dengan penduduk lokal dan merupakan langganan dari usahanya. Begitupun sebaliknya, orang Jawa yang melakukan hajatan juga mengundang masyarakat lokal sehingga hubungan timbal balik antara keduanya terjalin, misalnya hajatan naik rumah baru, meskipun acaranya sederhana (Saifuddin, 2019). Dalam berinteraksi dengan masyarakat lokal migran Jawa hadir serta berpartisipasi dalam kegiatan masyarakat lokal. Seperti acara pernikahan, aqiqah, dan hajatan yang lain.

\section{Panguyuban Orang Jawa}

Manusia merupakan makhluk yang memiliki keinginan untuk menyatu dengan sesamanya serta dengan alam lingkungan disekitarnya. Dengan menggunakan pikiran, naluri, perasaan, keinginan dan sebagainya menusia memberi reaksi dan melakukan interaksi dengan lingkungannya. Pola interaksi sosial dihasilkan oleh hubungan yang berkesinambungan dalam suatu masyarakat. Manusia memiliki banyak budaya dan adat istiadat yang berhubungan dengan masyarakat dan agama. Dari berbagai budaya yang ada, dapat dikaitkan hubungan dengan agama dan masyarakat dalam melestarikan budaya (Salmiati, 2017). Dalam pelestarian budaya peranan masyarakat sebagai individu dalam kelompok sosial sangat berperan penting.

Hampir semua manusia pada awalnya merupakan anggota kelompok sosial yang dinamakan keluarga. Suatu kelompok sosial cenderung untuk tidak menjadi kelompok sosial yang statis, tetapi selalu berkembang serta mengalami perubahan-perubahan (Soekanto, 1982). Perubahan yang terjadi merupakan keniscayaan dalam kehidupan bermasyarakat agar 
kehidupan tidak bersifat statis. Dan untuk melakukan perubahan setiap individu harus sadar bahwa peranan sebagai bagian dari kelompok sosial. Paguyuban merupakan bentuk kehidupan bersama dimana anggotaanggotanya diikat oleh hubungan batin yang murni dan bersifat kekal. Dasar hubungan tersebut adalah rasa cinta dan rasa kesatuan batin yang memang telah dikodratkan. Keberadaan perkumpulan atau paguyuban etnik atau kedaerahan cenderung membentuk masyarakat seolah-olah terkotak-kotak. Terutama karena hanya memperlihatkan ciri khas etnik atau kedaerahannya. Selain itu juga sebagai suatu cara untuk menjaga keamanan hidup di daerah perantauan yang masyarakatnya bersifat majemuk. Dengan demikian perkumpulan atau paguyuban etnik atau kedaerahan yang mereka bentuk ini, terkesan mempunyai fungsi sosial, yaitu untuk memperkuat identitas agar tetap lekat dengan daerah asal walaupun berada di daerah perantauan (Astuti, 1999).

Suatu kelompok dapat dinamakan perkumpulan atau paguyuban yang bersifat etnik atau kedaerahan, apabila dilihat dari dasar keanggotaan suatu paguyuban atau perkumpulan tersebut. Kalau disebut perkumpulan atau paguyuban etnik, berarti dasar keanggotaannya adalah suku bangsa (etnis), sehingga warna kultural pada paguyuban etnik akan lebih jelas. Dengan demikian suatu perkumpulan atau paguyuban etnik, pasti mempunyai anggota yang berasal dari satu suku bangsa. Satu suku bangsa adalah suatu golongan manusia yang terikat oleh kesadaran dan identitas akan kesatuan kebudayaan. Seringkali kesadaran dan identitas itu dikuatkan pula oleh kesatuan bahasa (Astuti, 1999)

Paguyuban bahwa sebuah wadah yang menghimpun sekelompok etnis ataupun bentuknya (paguyuban primordial atau organisasi 
kedaerahan), pembentuknya senantiasa dilatarbelakangi oleh suatu upaya untuk menghadapi lingkungan perantauan yang berbeda dengan lingkungan asalnya(Lubis, 2009). Begitu pula yang terjadi pada migran Jawa di Kecamatan Lilirilau. Sesama orang Jawa yang bermigrasi di Kecamatan Lilirilau Kabupaten Soppeng yang memiliki rasa senasib di daerah rantau yang jauh dari keluarga, hal tersebut mendorong orang Jawa di Kecamatan Lilirilau membentuk perkumpulan atau paguyuban sesama orang Jawa.

Salah satu upaya atau cara untuk tetap menjaga solidaritas dan keharmonis sesama orang Jawa di Kecamatan Lilirilau yaitu dengan membentuk perkumpulan orang Jawa. Dengan adanya Paguyuban tersebut melahirkan rasa persatuan, solidaritas satu sama lain. Bahkan hubungan mereka jauh lebih erat dibandingkan hubungan mereka di kampung halaman, walaupun mereka berasal dari daerah yang berbeda namun kebersamaan dan jiwa solidaritas mereka tetap terjalin dengan harmonis.

Paguyuban atau perkumpulan orang Jawa di Kecamatan Lilirilau rutin melakukan kegiatan-kegiatan sederhana misalnya, melakukan pengajian dan membentuk kelompok arisan sesama orang Jawa, dengan kegiatan tersebut secara tidak langsung hubungan emosional mereka lebih terjalin, sesuai penuturan informan "sesama orang Jawa rutin melakukan arisan tiap bulannya. Setiap satu kelompok itu ada 30 sampai 40 orang, laki-lakinya untuk yasinan dan pengajian dan tempat digilir" (Listianti, 2019).

Kehidupan Ekonomi Migran Jawa di Kecamatan Lilirilau 
Begitu banyak orang bermigrasi hanya untuk mendapatkan mata pencaharian atau pekerjaan yang lebih baik dan layak. Hal tersebut disesuaikan dengan tingkat pendidikan dan keterampilan yang dimiliki. Sama halnya dengan Orang Jawa yang datang di Kecamatan Lilirilau juga berharap akan mendapatkan mata pencaharian yang lebih baik, dikarenakan daerah asal mereka tidak banyak menyediakan lapangan pekerjaan sesuai keterampilan yang mereka miliki.

Masyarakat Pulau Jawa terkenal dengan kelompok yang ulet dalam mencari sumber penghidupan. Sudah lama mereka dikenal sebagai bangsa perantau yang banyak memperoleh keberhasilan ditanah rantau, rela meninggalkan sanak saudara dikampung demi bersaing dalam meningkatkan taraf kehidupan keluarga. Setelah nantinya berhasil di daerah rantauan barulah keluarganya diajak ikut merantau (Salmiati, 2017).

Berdasarkan hasil wawancara kehidupan ekonomi orang Jawa di Kecamatan Lilirilau mayoritas menekuni pekerjaan dibidang kuliner. Orang Jawa di Kecamatan Lilirilau telah menekuni bisnis kuliner seperti mendirikan warung makan, bakso keliling dengan cita rasa makanan khas Jawa yang relatif sederhana dan harga terjangkau. Sepanjang pencarian informasi yang dilakukan oleh peneliti ditemukan beberapa jenis usaha kuliner orang Jawa di Kecamatan Lilirilau, sebagaimana dalam tabel berikut: 
Tabel 1. Usaha Kuliner Orang Jawa di Kecamatan Lilirilau

\begin{tabular}{clcl}
\hline No. & \multicolumn{1}{c}{ Jenis Usaha } & Jumlah & \multicolumn{1}{c}{ Keterangan Tempat } \\
\hline 1. & Penjual bakso & 7 & Warung \\
2. & Penjual bakso keliling & 30 & Gerobak/Motor \\
3. & Nasi goring & 5 & Warung \\
4. & Martabak/Gorengan & 4 & Gerobak \\
5. & Nasi kuning & 15 & Warung/Gerobak \\
6. & Sate & 3 & Warung \\
7. & Tahu/Tempe & 2 & Pabrik/Lapak \\
8. & Ayam goring & 2 & Warung \\
9. & Kue & 7 & Gerobak \\
10 & Roti & 1 & Gerobak \\
\hline \multicolumn{4}{c}{ Jumlah } \\
\hline
\end{tabular}

Sumber: hasil observasi

Kuliner yang paling banyak digeluti adalah penjual bakso keliling dengan alasan modal yang digunakan lebih sedikit dibandingkan membuka warung. Berjualan bakso keliling dapat berjualan di beberapa tempat, termasuk di daerah terpencil yang tidak ada warung baksonya (Kadi, 2019). Selain usaha dibidang kuliner Orang Jawa di Kecamatan Lilirilau juga menekuni usaha lain, misalnya penjual jamu 3 orang, jual beli barang bekas 2 orang, penjual baju 2 orang, jasa cukur 1 orang, usaha mebel 1 orang (hasil observasi, 2019).

\section{KESIMPULAN}

Berdasarkan pembahasan yang telah dipaparkan sebelumnya, adapun kesimpulan dalam penelitian ini adalah sebagai berikut: kedatangan orang Jawa di Kecamatan Lilirilau sejak 1970, namun jumlah masih kurang. Namun seiring berjalanan waktu, populasi orang Jawa kian bertambah, disebabkan oleh beberapa faktor. Faktor ekonomi akibat meningkatnya persaingan pada lapangan pekerjaan di daerah asal, dan alasan perkawinan. Selain faktor pendorong yang berasal dari daerah asal juga ada faktor penarik. Faktor penarik adalah faktor yang berasal dari daerah tujuan, yaitu: kesempatan untuk mendapatkan pekerjaan yang 
lebih baik, keadaaan lingkungan dan keadaan hidup yang menyenangkan, cerita tentang keberhasilan kerabat yang lebih dulu merantau di Kecamatan Lilirilau. Hubungan antara orang Jawa dengan orang Bugis di Kecamatan Lilirilau terjalin dengan harmonis. Orang Jawa juga memiliki paguyuban untuk meningkatkan persaudaraan, dan rasa senasib sebagai perantau. Paguyuban tersebut memiliki kegiatan-kegiatan seperti pengajian dan arisan sebagai silaturahmi. Hubungan sosial tergambarkan ketika kolaborasi dalam kegiatan sosial. Dampak dalam bidang ekonomi adalah terjalinnya hubungan kausalitas antara penjual dan pembeli. Orang Bugis menjadi konsumen pada warung-warung kuliner milik orang Jawa, begitupun sebaliknya orang Jawa menjadi konsumen hasil bumi milik orang Bugis.

\section{DAFTAR PUSTAKA}

[1]. Alkhudri, A. T., Dharmawan, A. H., Kinseng, R. A., \& Tjondronegoro, S. M. P. (2018). Metamorfosis Gerakan Sosial di Banten: Dari Romantisme Identitas ke Isu Agraria Lingkungan. Jurnal Sodality, 6(1), 24-31.

[2]. Astuti, R. (1999). Keberadaan paguyuban-paguyuban etnis di daerah perantauan dalam menunjang pembinaan persatuan dan kesatuan: kasus paguyuban keluarga Putra Bali di Yogyakarta. Direktorat Jenderal Kebudayaan.

[3]. Christiani, C., Tedjo, P., \& Martono, B. (2014). Analisis Dampak Kepadatan Penduduk Terhadap Kualitas Hidup Masyarakat Provinsi Jawa Tengah. Serat Acitya, 3(1), 102.

[4]. Indira, D., Mulyadi, R. M., \& Nasrullah, R. (2019). Komunitas Masyarakat Jawa di Desa Wanareja Sebagai Jejak Migrasi Masyarakat Jawa Ke Pangandaran. Sosiohumaniora, 21(1), 34-39.

[5]. Lubis, D. Y. M. (2009). Perbedaan Sikap Terhadap Pemutusan 
Hubungan Kerja di Tinjau dari Jenis Kelamin, Masa Kerja dan Status Perkawinan di PT. Timur Jaya Coldstorage Tanjung Balai. Universitas Medan Area.

[6]. Munir, R. (1981). Migrasi" dalam Dasar-dasar Demografi: edisi 2000. Jakarta: Lembaga Demografi FE UI Bekerjasama Dengan Lembaga Penerbit UI.

[7]. Rahmi, U. (2016). Massompa': Kajian Migrasi Orang Kassa ke Malaysia Timur (1959-1998). Jurnal Pattingalloang, 3(2), 85-93.

[8]. Sejarah, M. (1975). Terjemahan Nugroho Notosusanto. Jakarta: Yayasan Penerbit Universitas Indonesia.

[9]. Setiadi, E. M., \& Kolip, U. (2013). Pengantar sosiologi politik. Kencana.

[10]. Sjamsuddin, H., \& Nursam. (2007). Metodologi sejarah. Yogyakarta: Ombak.

[11]. Soekanto, S. (1982). Sosiologi suatu Pengantar. Jakarta (ID). PT Raja Grafindo Persada. Soemardjan, Selo \& Breazeale, Kennon. 1993. Cultural Change in Rural Indonesia: Impact of Village Development. Sebelas Maret University Press, Yayasan Ilmu-ilmu Sosial, and East-West.

[12]. Warsono, P. (2005). Arus balik kependudukan. Pustaka Sinar Harapan.

[13]. BPS, 2018. Kabupaten Soppeng Dalam Angka 2017. Soppeng: Badan Pusat Statistik.

[14]. Salmiati, 2017. Orang Jawa di Kecamatan Bengo Kabupaten Bone. Makassar: UNM.

\section{Sumber Wawancara}

[1]. Listianti, 2019. Wawancara [Interview] (Rabu September 2019).

[2]. Mualif, A., 2019. Wawancara [Interview] (Jumat September 2019). 
[3]. Nengsih, S., 2019. wawancara [Interview] (Rabu September 2019).

[4]. Riadi, S., 2019. Wawancara [Interview] (Rabu September 2019).

[5]. Saifuddin, 2019. Wawancara [Interview] (Kamis September 2019).

[6]. Sari, A., 2019. Wawancara [Interview] (Jumat September 2019). 